\title{
Effect of Sponsor-Event Fit on Company's Decision to Sponsor Sport Event
}

\author{
Billy Castyana $^{1}$, Mugiyo Hartono ${ }^{2}$, Rizqi Teguh Iskandar ${ }^{3}$ \\ \{billycastyana@mail.unnes.ac.id ${ }^{1}$, hartonofikunnes@gmail.com ${ }^{2}$, rizqi.teguh05@gmail.com ${ }^{3}$ \} \\ Universitas Negeri Semarang, Semarang, Indonesia ${ }^{123}$
}

\begin{abstract}
According to Speed, Richard, and Thompson, one of influencing factors of company to sponsor sport event is sponsor-event fit. This factor shows how congruence is event vision and company goal, where they will, not only, share their assets but also share their visions. This descriptive quantitative research used survey as its method with variables were goal, logo, suitability, market, brand positioning, and comany's decision. Population were decision maker of companies which ever become sport event, such as head of company, finance manager, and marketing manager. With purposive sampling method as sampling technique, this research also used modification 4 points likert scale quetionnaire as its instrument. From analysis data which used regression analysis, significance data showed .021 and its $<.050$ so sponsor-fit event have effect on the company's decision.
\end{abstract}

Keywords: Sport Management, Sport Sponsorship, Sport Event

\section{Introduction}

Along with the times there are many ways to do marketing and promotion. Competition between companies in marketing their products is the main reason, so that companies have different strategies from one another. This happened as a result of the higher growth of the company. According to Fauzi and Suhadak, high company growth reflects the broader reach of the company and shows good company performance due to an increase in company assets or sales [1]. One of them is the company's decision to sponsor sports events. Sponsorship has the role of a popular marketing communication tool used in marketing communications to communicate with consumers. According to Meenaghan, sponsorship is defined as an investment, either in cash or in-kind, in an activity, whether individual or event, which later serves as a key to accessing potential commercial aspects of these activities by investors [2]. In addition, sponsorship is also a commercial transaction, in which the donor expects remuneration from the recipient of the funds and both parties agree to give and receive each other [3]. According to Lamb et al, sponsorship can also be defined as a marketing activity in which the organization gets the right to use the company, product or brand name and logo with a contract of monetary giving and other support to the organization [4]. Therefore, sponsorship can be defined as promotional or marketing activities carried out by a company in the form of cash or products owned to obtain an advantage for the company and to support the activities of an organization. According to Lidia Evelina ${ }^{3}$, the benefits of sponsorship include that the company gets a good image and its name is increasingly recognized among the public and can collaborate with other parties for the company's needs. In addition, through the use of 
sponsorship, companies can reach their consumers and enrich consumers' knowledge about the company's own brands. With the increase in similar companies the way of marketing for each company is different and the company's decision to sponsor events because this is one way in a marketing strategy to reach the target market the company wants to reach [5].

An event is an activity held to commemorate important things throughout human life, either individually or in groups bound by custom, culture, tradition, and religion which is held for certain purposes and involves the community environment which is held at certain times Then sport can be defined in general as a person's physical and psychological activity which is useful for maintaining and improving the quality of one's health. So, a sports event can be defined as an activity related to a person's physical and psychological activities held in various sports fields and at certain times [6]. According to Lumintuarso, sports events contain two aspects as important factors that ensure the rolling of the sports industry, namely how to build sports (internal) and how to sell sports (external). The internal aspect involves community participation and infrastructure tools (tools), as a sports event builder (entertainer), while the external aspect includes the public, the media, and partners, as a quality sports event seller [7]. Sports events are also a very interesting activities to be used as sponsors media for companies because they are heavily covered by the media. According to Olejniczk and Alcher, sports sponsorship can be interpreted as an effort to form a strategic relationship between a company and sports property as a means of communicating brand messages to the general public, players or certain events [8]. Sports sponsorship can also be described as a business relationship between a sponsor and a sports entity for mutual benefit ${ }^{8}$. So, sports sponsorship can be interpreted as a relationship or collaboration with other parties as a means of conveying a product or brand to a company to be introduced to the general public through a sports event to obtain the same benefits. Because success in a sports event does not only focus on how to manage the organizing committee and the events at the event, but the involvement of sponsors also has a very influential role in the success of a sports event. Therefore, it is necessary to have a deeper discussion regarding which factors have the most influence on company decisions in sponsoring sporting events. This discussion can be used as input for sports event organizers and the government to pay attention to these factors in order to collaborate with various sponsors. However, to cooperate with the organizing committee, each company that will sponsor an activity must have the criteria and determining factors in making decisions whether to cooperate in a particular event. According to Speed and Thompson [9], one factors that influence company to become sponsor for sport event is the fit of sponsor and event. This factor shows how congruence is event vision and company goal, where they will, not only, share their assets but also share their visions. Ambient aromas that are assessed to be coherent with the retail context (for example, floral fragrance at a flower shop) may have a beneficial impact on choice processes, according to recent research on olfactory clues [10]. Odors that are out of place might be irritating. Source effects research has also emphasized the importance of source similarity as a factor of attractiveness [11]. McCracken's meaning transfer model highlights the necessity of continuity between the source's meanings and the product's intended meaning [9]. Sponsorship researchers ${ }^{12}$ have emphasized the importance of a link or "fit" between the sponsor and the sponsored event. Fit can be assessed on several different levels (e.g., functional characteristics, symbolic characteristics). We will not, however, explore the many bases of fit for the sake of brevity; instead, we will model perception of fit between sponsor and event using a single build. To avoid tying this construct to a specific degree of fit, we think of fit in a broad sense. Without limiting the variables used to evaluate fit, this construct gets into the respondent's views about the event and sponsor coupling, as well as the degree to which the pairing is perceived as well-matched or a good fit. 


\section{Methods}

This research is a quantitative descriptive study conducted to provide a more detailed description about the effect of sponsor-event fit to the company's decision to sponsor sports events. In this study, there are five independent variables and one dependent variable. The dependent variable of this study is the company's decision to sponsor sports events. The independent variables of this study are Goal's Fit, Logo's Fit, Matching between Event and Company, Company's Support, Brand Awareness. The population in this study were all companies throughout Central Java. However, there are company limitations in this study, namely industrial companies, sports industry companies, individual companies, companies that have sponsored corporate sports events that are willing to be respondents in this study. This study used a non-probability sampling technique is purposive sampling with a sample consisting of directors or company leaders, the administration and finance, and the marketing department. The research instrument used is an instrument that has been used by Speed and Thompson with the necessary modifications in the form of a checklist using a 4-point Likert scale with assessment points, namely Strongly Agree, Agree, Disagree, and Strongly Disagree. Regression techniques are used to test if there is any effect of sponsor-event fit to the company's decision to sponsor sports events.

\section{Result and Discussion}

\subsection{Result}

After processing the data, the results of the $\mathrm{T}$ test show a significance value $<.05$ or have a value of T Count $>\mathrm{T}$ Table, so there is an effect of variable $\mathrm{X}$ on variable $\mathrm{Y}$. By using the formula $\mathrm{T}$ table $=\mathrm{t}(\alpha / 2 ; \mathrm{nk}-1)$ it is obtained table results of 2.032. The significance value above is 0.021 which means the significance value $<.05$ and has a $\mathrm{T}$ count value of 2.413 and a $\mathrm{T}$ table value of 2.032 which means the value of $\mathrm{T}$ Count $>\mathrm{T}$ Table, it can be seen that there is an influence of sponsor-event fit on the results of the company's decision to sponsor. sporting events.

Table 1. Regression Analysis.

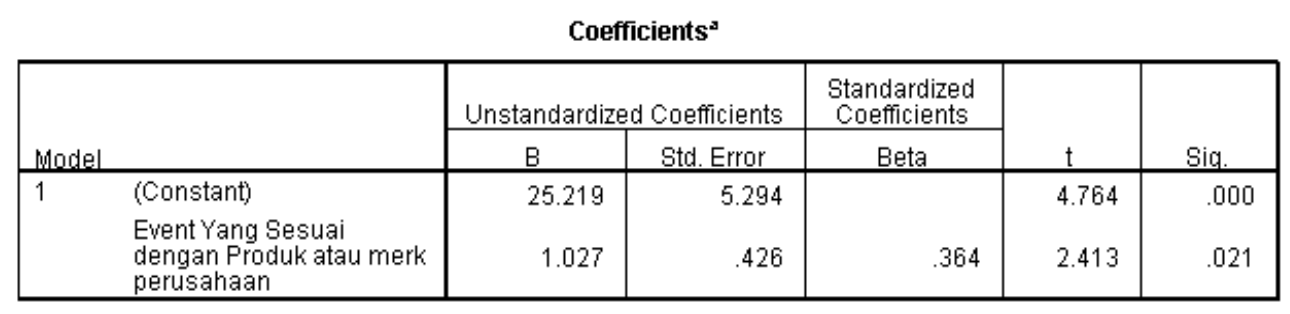

\subsection{Discussion}

It can be observed from the results of the data processing that the company considers sponsor-event fit when giving sponsorship. This consideration is made to align the aims of the firm with the upcoming events, one of which is to ensure that the company's name or brand is 
familiar to the event's target market. Sponsoring sporting events, according to Olejniczk and Alcher, can develop a strategic link between a corporation and a sports property, as well as communicate the brand message to the wider public. A strategic match between a sponsoring corporation and a sporting event [13], or a functional or image-based match, is what fit is informally defined as [12]. Fit has often been referred to as congruence when analyzing parallels in context between two people [14].

According to schema theory, assimilation effects occur as the fit between a sponsor brand and a sport event brand increases, shifting the event's quality to the sponsor brand [15]. By affecting other variables such as cognitive and affective responses [15], as well as sponsor receptiveness and honesty [17], sponsorships with a high fit with an event will raise brand attitudes [16] and increase the likelihood of the sponsor brand's purchasing intentions. Sponsors pay money to reap the benefits of great brand image transfer during an event, which is heavily influenced by a good fit between the event and the sponsor [18]. Customers may transfer some of the positive connotations and traits from the event to the sponsor if the sponsor is thought to have a strong functional or image-based match with the event [9]. It is said to be operationally fit when participants wear the sponsoring goods during an event (for example, sport shoes), whereas image fit occurs when the event's image is identical to that of the sponsoring brand.

According to the brand extension literature, an effective brand extension is more likely when the original brand and the brand extension are in some way compatible, because greater fit activates category-based processing, resulting in the transfer of the original brand's assessments to the extension [19]. In a similar line, greater perceived congruence between a sponsor and a sporting event may lead to sponsorship categorization [20]. When there is a high level of congruence, images and assessments linked with a well-known event such as the World Cup can be utilized to evaluate the sponsoring brand and sponsorship efforts. Due to the unplanned pairing [21], incongruence, or a lack of congruence, between a sponsor and a sporting event, prompts cognitive elaboration on the sponsorship. Increased elaboration, as a result of the negative valence of low congruence, not only generates more negative views and comparisons, but also makes them more available as inputs in a subsequent sponsorship assessment, resulting in a less favorable attitude toward the sponsorship and a decrease in brand equity [22]. As a result, unless the sponsoring company is seen to be congruent with the sponsored event on some level, even a well-executed sponsorship campaign with consumerfriendly, positive features may not result in positive image transfer. In the worst-case situation, consumers may reject the brand due to confusing brand positioning and sponsored behavior [22].

\section{References}

[1] MARYANTI, Eny. Analisis Profitabilitas, Pertumbuhan Perusahaan, Pertumbuhan Penjualan dan Struktur Aktiva terhadap Struktur Modal pada Perusahaan Sektor Industri Barang Konsumsi yang terdaftar di Bursa Efek Indonesia (Studi Empiris pada Perusahaan Manufaktur yang Terdaftar di Bursa Efek Indonesia Tahun 2012-2014). Riset Akuntansi dan Keuangan Indonesia, 2016, 1.2: 143-151.

[2] ALBAR, Berri Brilliant. Pengaruh Sponsorship Copa Indonesia Terhadap Citra Merek Dji Sam Soe. Jurnal Manajemen dan kewirausahaan, 2011, 2.3.

[3] EVELINA, Lidia. Paradigma Baru Sponsor Sebagai Mitra Penyelenggaraan Event. Humaniora, 2011, 2.2: 986-995. 
[4] SALMA, Aqidah Nuril. Pengaruh Sponsorship Dalam Meningkatkan Brand Awareness (Studi pada Sponsorship Garuda Indonesia Terhadap Liverpool FC sebagai Global Official Airline Partner). INJECT (Interdisciplinary Journal of Communication), 2017, 2.1: 1-26.

[5] JONATAN, Jonatan; LAKSMIDEWI, Theresia Dwinita. PENGARUH SPORT SPONSORSHIP TERHADAP REPURCHASE INTENTION. Prosiding Working Papers Series In Management, 2018, 10.1 .

[6] MARYADI, Rendi; HERLIANI, Shanti. Perancangan Sistem Informasi Promosi Event (Studi Kasus: Kota Bandung). Konferensi Nasional Sistem Informasi (KNSI) 2018, 2018.

[7] SUKARMIN, Yustinus. Pemasaran olahraga melalui berbagai event olahraga. Medikora, 2010, 2.

[8] ISKANDAR, Rizqi Teguh, et al. SURVEI FAKTOR YANG MEMPENGARUHI KEPUTUSAN PERUSAHAAN DALAM MENSPONSORI EVENT OLAHRAGA DI TEGAL. 2020. PhD Thesis. UNNES.

[9] SPEED, Richard; THOMPSON, Peter. Determinants of sports sponsorship response. Journal of the academy of marketing science, 2000, 28.2: 226-238.

[10] MITCHELL, Deborah J.; KAHN, Barbara E.; KNASKO, Susan C. There's something in the air: Effects of congruent or incongruent ambient odor on consumer decision making. Journal of Consumer Research, 1995, 22.2: 229-238.

[11] DE VEIRMAN, Marijke; CAUBERGHE, Veroline; HUDDERS, Liselot. Marketing through Instagram influencers: the impact of number of followers and product divergence on brand attitude. International journal of advertising, 2017, 36.5: 798-828.

[12] MAZODIER, Marc; MERUNKA, Dwight. Achieving brand loyalty through sponsorship: the role of fit and self-congruity. Journal of the Academy of Marketing Science, 2012, 40.6: 807-820.

[13] BRODIE, Roderick J., et al. Customer engagement: Conceptual domain, fundamental propositions, and implications for research. Journal of service research, 2011, 14.3: 252-271.

[14] ZDRAVKOVIC, Srdan; MAGNUSSON, Peter; STANLEY, Sarah M. Dimensions of fit between a brand and a social cause and their influence on attitudes. International Journal of Research in Marketing, 2010, 27.2: 151-160.

[15] BISCAIA, Rui, et al. Sport sponsorship: The relationship between team loyalty, sponsorship awareness, attitude toward the sponsor, and purchase intentions. Journal of Sport Management, 2013, 27.4: 288-302.

[16] LEE, Hyung-Seok; CHO, Chang-Hoan. The matching effect of brand and sporting event personality: Sponsorship implications. Journal of Sport Management, 2009, 23.1: 41-64.

[17] SMITH, Aaron; GRAETZ, Brian; WESTERBEEK, Hans. Sport sponsorship, team support and purchase intentions. Journal of Marketing Communications, 2008, 14.5: 387-404.

[18] ABREU NOVAIS, Margarida; ARCODIA, Charles. Measuring the effects of event sponsorship: Theoretical frameworks and image transfer models. Journal of Travel \& Tourism Marketing, 2013, 30.4: 308-334.

[19] SUNG, Yongjun; KIM, Jooyoung. Effects of brand personality on brand trust and brand affect. Psychology \& Marketing, 2010, 27.7: 639-661.

[20] BARONE, Michael J.; NORMAN, Andrew T.; MIYAZAKI, Anthony D. Consumer response to retailer use of cause-related marketing: Is more fit better?. Journal of retailing, 2007, 83.4: 437445.

[21] HAN, Sangpil, et al. The effectiveness of image congruence and the moderating effects of sponsor motive and cheering event fit in sponsorship. International Journal of Advertising, 2013, 32.2: 301317.

[22] SIMMONS, Carolyn J.; BECKER-OLSEN, Karen L. Achieving marketing objectives through social sponsorships. Journal of marketing, 2006, 70.4: 154-169. 